\title{
Introducing adolescent livelihoods training in the slums of
} Allahabad, India

\author{
Monica J. Grant \\ Barbara Mensch \\ Population Council \\ Mary Philip Sebastian \\ Population Council
}

Follow this and additional works at: https://knowledgecommons.popcouncil.org/departments_sbsr-pgy

Part of the Demography, Population, and Ecology Commons, Family, Life Course, and Society Commons, Gender and Sexuality Commons, and the International Public Health Commons How does access to this work benefit you? Let us know!

\section{Recommended Citation}

Grant, Monica J., Barbara Mensch, and Mary Philip Sebastian. 2011. "Introducing adolescent livelihoods training in the slums of Allahabad, India," Promoting Healthy, Safe, and Productive Transitions to Adulthood Brief no. 2. New York: Population Council. 


\title{
Introducing adolescent livelihoods training in the slums of Allahabad, India
}

\author{
Prepared by Monica J. Grant, Barbara S. Mensch, and Mary P. Sebastian
}

W hile all adolescents in India face a rapidly changing economic environment, the life choices of girls are very different from those of boys. Girls are much less likely than boys to be engaged in economic activities; by ages $15-19$ more than 40 percent of boys are economically active compared to about 25 percent of girls (ILO 1998). When young women do participate in incomegenerating activities, it is often in home-based work for which they may not be remunerated. Even in instances when young women are paid for their labor, they may not retain control of their income.

For girls, the lack of opportunities to generate income is coupled with restricted physical mobility within the community and limited decisionmaking power within the household (Sebstad and Singh 1998; Mensch, Bruce, and Greene 1998). Furthermore, nearly half of 20-24-year-old women in India were married by age 18 (IIPS and ORC Macro 2000). Most young women have little say about the timing of marriage or the choice of spouse, and after marriage most young women have limited power within their new household (Jejeebhoy 1998).

The Population Council and its partners are promoting a "livelihoods approach" that aims to expand the decisionmaking power of young women by building social networks and developing financial and income-generating capacities. As broadly conceived, the livelihoods approach to adolescent programs attempts to provide technical and life skills and seeks to transform the ways in which girls view themselves and are perceived by others in the community. Although a wide variety of livelihoods programs for adult women exist in India, few focus on adolescents. Of those that do, few employ rigorous scientific methods to evaluate the impact of the program.

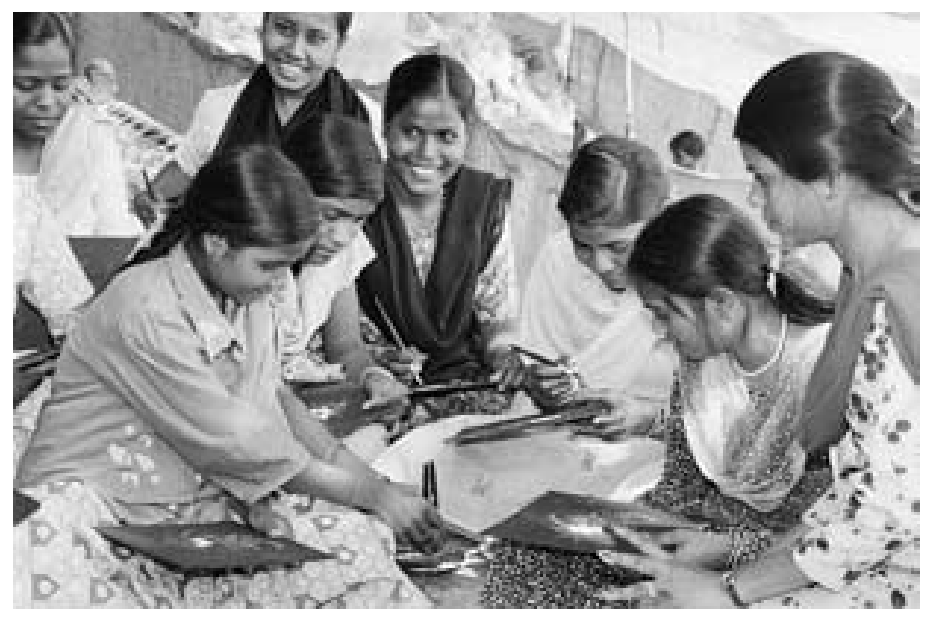

Livelihoods programs have the potential to increase the agency and decisionmaking power of young women.

Testing the feasibility and acceptability of a pilot livelihoods project To build the evidence base for adolescent livelihoods programs, in 2001 the Population Council teamed with CARE-India to develop a pilot project for adolescent girls in the urban slums of Allahabad, Uttar Pradesh. Since 1995, CARE-India has been providing reproductive health services for adult women (aged 20-49); in 1999 it added reproductive health education for adolescent boys and girls (aged 10-19).

The Council's pilot project integrated livelihoods activities for adolescent girls aged 14-19 into CARE's reproductive health program for slum dwellers. The study area was divided into an experimental and a control area. 
At the onset of the project, literate 14-19-year-old girls who had their parents' permission were trained to be peer educators. These girls attended a six-day reproductive health training course and a twoday training course to improve their communication skills. Each peer educator was expected to visit every household in her locality and invite all eligible young women to participate in the project. When approximately 20 girls had been given permission to participate, a group was formed that met once a week at the home of a peer educator.

Group sessions on reproductive health were held weekly in both experimental and control areas for 7-10 weeks. Participants residing in the experimental areas also received vocational counseling, savings account information, and follow-up support from a peer educator. Over a 10-month period, 19 vocational courses were offered, including tailoring, pot decoration, mehndi (painting of hands or feet), candle making, creative painting, rug weaving, mending and embroidery, beekeeping, food preservation, and basic cooking.

Nearly 80 percent of participants completed two or more courses. Peer educators also discussed various savings options available in the community and helped girls open savings accounts in their own names. All accounts were opened in post offices, which offered



Unmarried girls need and appreciate spaces where they can congregate safely and develop their skills. simpler procedures and required lower initial deposits than banks. Baseline and endline surveys measured the effect of the project by comparing changes in various behavioral and attitudinal outcomes for adolescents in the control and experimental areas before and after the intervention.

\section{Findings from the baseline survey}

The baseline survey clearly indicated the appropriateness of a project that addresses the capabilities of and opportunities for young women. In Allahabad substantial gender differences were found among adolescents in mobility, time-use patterns, and savings and work experience. The data revealed several noteworthy findings:

- Approximately half of girls indicated that they had not traveled outside of Allahabad during the past six months, compared to only about one-quarter of boys.

- Girls were much more likely than boys to report that they needed to seek permission to make visits outside of their homes. Both boys and girls said that there are no places in the community where unmarried girls can safely congregate for any purpose, a finding that reflects local norms governing the limited use of public space by unmarried girls.

- Sharp differences between boys and girls were seen in the amount of time spent on chores: girls reported spending almost four times as many hours as boys.

- The proportion of boys who reported that they have ever worked for pay is five times greater than the proportion of girls.

- Although girls were much less likely to work for pay, they were more inclined to save: 54 percent of girls and 26 percent of boys had some savings.

- Knowledge of certain reproductive health topics was low. For example, very few adolescents in the survey knew about the fertile period of a woman's menstrual cycle. Although more than 90 percent of respondents of both sexes reported knowing at least one contraceptive method, only about 33 percent of the girls spontaneously reported knowing about condoms as compared with 82 percent of the boys. Moreover, only 37 percent of the girls knew that condoms can protect against HIVIAIDS, as compared to 84 percent of the boys.

Evaluation of the project

The project had some demonstrable effects on adolescent girls in Allahabad. Girls in the experimental areas were significantly more 


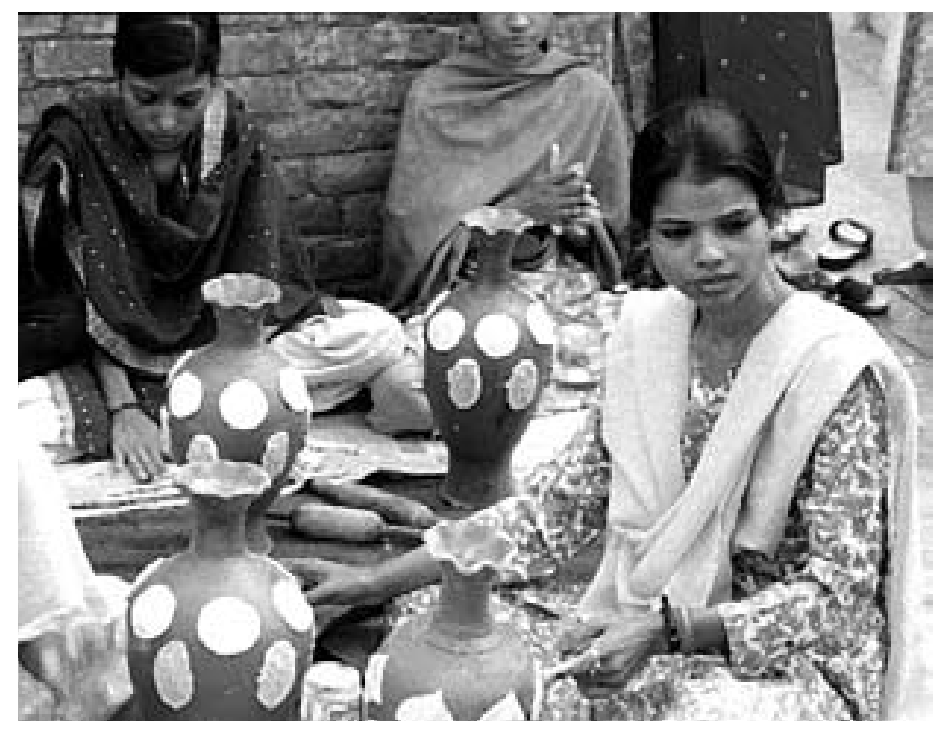

Participants in the experimental area attended vocational training classes. Over a period of ten months, 19 vocational courses were offered.

likely than the matched control respondents to know about safe locations for unmarried women to congregate, be a member of a group, score higher on indexes measuring social skills and selfesteem, be informed about reproductive health, and spend time on leisure activities. On the other hand, the project did not have a demonstrable effect on gender role attitudes, mobility, work expectations, time use, or labor market work, likely because of the short duration of exposure, as well as the limited number of times that groups convened.

The greatest changes were found in those measures that most closely reflected the content of the project. Participation provided a context in which young women could build friendships, develop critical thinking, and gain self-confidence while working with their peer group. The vocational training classes and savings groups also required participants to interact with adults and with individuals from outside the community. Girls in the experimental areas demonstrated a greater increase in their social skills than did girls from the control areas. Likewise, girls in the experimental areas were more likely to express knowledge of safe places for unmarried women to gather and to identify themselves as group members. Although all girls met in groups at the home of a peer educator, those in the experimental areas spent more time together and participated in a wider variety of activities.
It is highly encouraging that project participants showed a noticeable increase in reproductive health knowledge relative to control respondents. Although some of this change may be related to better attendance in the experimental areas, some unmeasured aspect of the livelihoods component may have encouraged the retention of the reproductive health information.

Finally, more than 80 percent of participants in the experimental areas continued to use their vocational skills after the project ended, and more than 50 percent were able to open savings accounts in their name at the local post office. However, only 10 percent earned income from selling products that they made.

Although the girls showed interest in opening savings accounts and by law are permitted to do so, male staff at the post office were reluctant to assist adolescent girls; thus program staff had to act as intermediaries in order for girls to open savings accounts. Moreover, girls were reluctant to travel alone to the post office; thus many did not continue to actively use their savings accounts.

Lessons learned

Several lessons emerged from this pilot project. We found that a livelihoods project for adolescent girls was both acceptable to parents in this traditional slum community and feasible to implement. Short-term projects can raise awareness, self-esteem, social skills, knowledge of safe spaces, and group identification; however, they cannot be expected to alter the structure of opportunities available to adolescent girls. To reduce deeply entrenched gender disparities and enhance girls' ability to influence their own lives, future projects should incorporate greater interaction with other participants and with older family members. Moreover, increased effort should be devoted to developing group cohesion and improving young women's communication, negotiation, and decisionmaking skills.

\section{Expanding livelihoods efforts}

CARE-India has incorporated the project's livelihoods approach into its adolescent programs. One of the NGOs in Allahabad (Sahyog), familiar with our project activities, started a similar program with adolescents in Uttar Pradesh. Several other groups visited the project site to learn how to conduct livelihoods training for adolescents. The successful scaling-up of the savings component would require addressing the negative attitudes of post office staff and, most likely for the youngest girls, creation of "savings clubs" with adult mentors. 


\section{References and related publications}

Acharya, R., S. Kalyanwala, S. J. Jejeebhoy et al. 2009. Broadening girls' horizons: Effects of a life skills education programme in rural Uttar Pradesh. New Delhi: Population Council.

International Institute for Population Sciences (IIPS) and ORC Macro. 2000. National Family Health Survey (NFHS-2), 1998-99: India. Mumbai: IIPS.

International Labor Organization (ILO). 1998. Yearbook of Labor Statistics 1998. Geneva: ILO.

Jejeebhoy, Shireen J. 1998. "Adolescent sexual and reproductive health: A review of the evidence from India," Social Science \& Medicine 46(10): 1275-1290.

Mensch, Barbara S., Judith Bruce, and Margaret E. Greene. 1998. The Uncharted Passage: Girls' Adolescence in the Developing World. New York: Population Council.

Mensch, Barbara S., Monica J. Grant, Mary P. Sebastian, Paul C. Hewett, and Dale Huntington. 2004. "The effect of a livelihoods intervention in an urban slum in India: Do vocational counseling and training alter the attitudes and behavior of adolescent girls?" Policy Research Division Working Paper No. 194. New York: Population Council.
Population Council and International Center for Research on Women. 2000.

"Adolescent girls' livelihoods: Essential questions, essential tools: A report on a workshop." New York: Population Council and ICRW.

Sebstad, Jennefer and Sagri Singh. 1998. "Adolescent livelihoods programmes: A preliminary review." New Delhi: Population Council.

\section{Donors}

Department for International Development (DFID), The Andrew W. Mellon Foundation, United States Agency for International Development (USAID)

\section{Partner institutions}

Centre for Operations Research and Training (CORT), CARE-India

\section{Research collaborators}

Shahina Begum, Wesley Clark, Paul Hewett, Dale Huntington, Sohini Roychowdhury, Nirmala Selvam, Aditya Narain Singh

\section{Population Council}

The Population Council changes the way the world thinks about critical health and development issues. We seek to understand the causes and consequences of gender inequality and the disparities in opportunity that arise during adolescence. We provide the evidence for better on-theground programs and policies that ensure successful and productive transitions to adulthood in developing countries. www.popcouncil.org

(c) 2011 The Population Council, Inc. 